\title{
NASKAH DRAMA SENJA DENGAN DUA KELELAWAR KARYA KRIDJOMULYO: KAJIAN PSIKOLOGI SASTRA DAN RELEVANSINYA SEBAGAI BAHAN AJAR APRESIASI DRAMA DI SEKOLAH MENENGAH ATAS
}

\author{
Akbar Bagus Wicaksono, Ani Rakhmawati, Raheni Suhita \\ Universitas Sebelas Maret \\ Surel : akbar.guswicak@student.uns.ac.id
}

\begin{abstract}
This research aims to explain: (1) characters character in the drama script Senja Dengan Dua Kelelawar; (2) the inner conflicts experienced by the characters in the drama script Senja Dengan Dua Kelelawar; and (3) the relevance of the drama Senja Dengan Dua Kelelawar as a teaching material for drama appreciation at senior high school. This study uses a literature psychology study, which uses a psychological approach to knowing the character of the character through observation of behavioral characters. The results of this study are descriptions of: (1) the characterization of the characters in the Drama Senja Dengan Dua Kelelawar which differ from each character. This is done to build a storyline that matches the theme of the drama script; (2) the inner conflicts experienced by the characters in the drama drama Senja Dengan Dua Kelelawar are very complex. Every inner conflict experienced by a character can be described through psychoanalytic theory with a focus on the study of the id, ego, and superego; and (3) the relevance of the Drama of Senja Dengan Dua Kelelawar as a teaching material for drama appreciation in high schools by paying attention to aspects of language, students' psychological development, and cultural background.
\end{abstract}

Keywords: psychology, drama, Senja dengan Dua Kelelawar

\begin{abstract}
Abstrak: Penelitian ini bertujuan untuk menjelaskan: (1) perwatakan para tokoh dalam naskah drama Senja Dengan Dua Kelelawar; (2) konflik batin yang dialami para tokoh dalam naskah drama Senja Dengan Dua Kelelawar; dan (3) relevansi naskah drama Senja Dengan Dua Kelelawar sebagai bahan ajar apresiasi drama pada sekolah menengah atas. Penelitian ini menggunakan sebuah kajian psikologi sastra, yakni menggunakan pendekatan psikologi untuk mengetahui watak dari tokoh melalui pemerhatian terhadap tingkah laku tokoh. Hasil penelitian ini adalah deskripsi tentang: (1) perwatakan para tokoh dalam naskah drama Senja Dengan Dua Kelelawar yang berbeda-beda dari masingmasing tokoh. Hal tersebut dilakukan untuk membangun jalan cerita yang sesuai dengan tema dari naskah drama; (2) konflik batin yang dialami para tokoh dalam naskah drama Senja Dengan Dua Kelelawar sangat kompleks. Setiap konflik batin yang dialami tokoh dapat diuraikan melalui teori psikoanalisis dengan fokus kajian pada id, ego, dan superego; dan (3) relevansi naskah drama Senja dengan Dua Kelelawar sebagai bahan ajar apresiasi drama pada sekolah menengah atas.
\end{abstract}

Kata kunci: psikologi sastra, naskah drama, Senja Dengan Dua Kelelawar

\section{PENDAHULUAN}

Naskah drama merupakan salah satu bentuk dari karya sastra yang sangat diminati oleh masyarakat luas. Karya sastra yang dulce et utile dapat berperan dan 
mempunyai andil yang besar dalam pembangunan masyarakat khususnya perihal perbaikan sikap dan sifat masyarakat. Perbaikan tersebut bisa sebagai salah satu upaya mengatasi permasalahan kehidupan. Menurut Endraswara (2013: 2) menyatakan sastra adalah alat (wahana) untuk mengajarkan kearifan hidup. Suharianto (dalam Sehandi, 2014: 67) juga menyampaikan pendapat bahwa hakikat karya sastra adalah kehidupan yang dihidangkan dengan gerak di atas panggung tersebut bukanlah kehidupan yang riil, tetapi kehidupan yang telah melalui proses imajinasi dan kreasi pengarang atau kehidupan menurtu penafsiran pengarang.

Menurut Budianta dkk (2002: 95) drama adalah sebuah genre sastra yang penampilan fisiknya memperlihatkan secara verbal adanya dialogue atau cakapan di antara tokoh-tokoh yang ada. Banyak sekali pelajaran hidup yang oleh pengarang diangkat dan direproduksi menjadi sebuah naskah drama. Nurgiyantoro (2013: 3) menegaskan bahwa fiksi merupakan hasil dialog, kontemplasi, dan reaksi pengarang terhadap lingkungan dan kehidupan. Tidak benar jika fiksi dinilai hanya dari segi hasil kerja khayalan, namun juga terdapat penghayatan dan perenungan secara mendalam. Keberadaan naskah drama yang sangat strategis menjadikan naskah drama sebagai kebutuhan nurani yang tidak bisa dipisahkan dengan pendidikan. Pendidikan juga berupaya melestarikan serta mengedukasikan pesan moral yang dibangun pengarang dalam naskah drama. Hal tersebut menjadikan naskah drama sangat penting untuk dipelajari.

Tokoh fiktif yang terdapat dalam cerita berperan penting dalam pengembangan jalan cerita. Menurut Abrams (dalam Nurgiyantoro, 2013:247) menyatakan pendapat bahwa tokoh cerita atau karakter adalah orang-orang yang ditampilkan dalam sesuatu karya naratif, atau drama, yang oleh pembaca ditafsirkan memiliki kualitas moral dan kecenderungan tertentu seperti yang diekspresikan dalam ucapan dan apa yang dilakukan dalam tindakan. Kenyataan tersebut menjadi sangat relevan bagi pengarang untuk membahas masalah manusia nyata yang diperankan oleh tokoh fiktif naskah drama. Tokoh dalam naskah drama sangat penting keberadaannya. Tokoh diperlukan untuk mengaktua-lisasikan pesan sastra dan bahasa yang terdapat dalam dialog tersebut. Isi naskah drama tetap memperhatikan keindahan penggunaan eksitensi sastra yang cenderung dipandang sebagai sesuatu 
yang indah dan berguna. Tuntutan ini menjadikan naskah drama sebagai karya fiksi harus mampu berinteraksi dengan lingkungan melalui pembentukan sifat bermasyarakat dalam pesan yang disampaikan oleh tokoh-tokoh fiktif tersebut.

Tokoh fiktif dalam naskah drama seperti halnya manusia nyata yang ada di kehidupan bermasyarakat, mempunyai sifat masing-masing yang disertakan oleh penciptanya. Hal sejalan juga disampaikan oleh Rokhmansyah (2014: 34) menjelaskan bahwa tokoh cerita adalah individu rekaan yang mempunyai watak dan perilaku tertentu sebagai pelaku yang mengalami peristiwa dalam cerita. Adapun watak para tokoh menurut Waluyo (2003 : 17-19) Watak para tokoh dalam fiksi digambarkan dalam tiga dimensi, yaitu dimensi fisik (jasmaniah), dimensi psikis (kejiwaan), dan dimensi sosiologis (latar belakang kekayaan, pangkat, dan jabatan). Tokoh cerita menempati posisi strategis sebagai pembawa dan penyampai pesan, amanat, moral, atau sesuatu yang sengaja ingin disampaikan kepada pembaca (Nurgiyantoro, 2013: 249).

Konflik tercipta ketika adanya kesenjangan yang terjadi antara para tokoh, seperti yang disampaikan oleh beliau. Kesenjangan itu terjadi bisa terjadi oleh beberapa faktor yang mempengaruhi, dan salah satunya adalah perbedaan pandangan, sifat dan sikap antara para tokoh. Menurut Nurgiyantoro (2013: 178) konflik (conflict), yang notabene adalah kejadian yang tergolong penting, akan berupa peristiwa fungsional, utama, atau kernel dalam pengategorian di atas. Hal selaras disampaikan oleh Waluyo (2003: 7) dasar teks drama adalah konflik manusia yang digali kehidupannya. Menurut Sehandi (2014: 124) secara umum konflik dalam karya sastra dapat digolongkan menjadi dua jenis, yakni konflik internal dan konflik eksternal karya sastra. Konflik internal adalah permasalahan yang terjadi dalam diri seorang tokoh yang mengalami pergulatan dalam dirinya sendiri tanpa disebabkan atau dipengaruhi orang lain di sekitarnya. Konflik eksternal adalah permasalahan yang terjadi karena faktor lain di luar diri sang tokoh.

Pengarang mengembangkan cerita melalui perilaku tokoh, perlu memahami terkait kepribadian tokoh yang memiliki sikap yang sesuai dengan perannya dalam cerita. Hal ini memerlukan pemahaman terkait dengan psikologi yang sangat jelas 
terlibat. Pengetahuan psikologi diperlukan juga untuk menyamakan presepsi kajian psikologi mempelajari perilaku manusia dengan perilaku tokoh drama. Roekhan (dalam Suaka, 2014: 230) mengatakan, psikologi dan karya sastra memiliki hubungan fungsional yakni sama-sama berguna untuk sarana mempelajari keadaankeadaan kejiwaan orang lain.

Psikologi mempunyai cara pandang terhadap dunia sastra yang melibatkan perilaku manusia sebagai pemeran penting dalam jalan cerita yang disebut dengan psikologi sastra. Cerita yang tidak lepas dari aspek kehidupan diproduksi dan dikreasikan dengan mewarnai perilaku tokoh. Psikologi sastra memberikan fokus pengembangan kajian pada masalah yang berhubungan dengan unsur-unsur kejiwaan tokoh-tokoh fiksional yang terdapat dalam sastra. Secara kejiwaan, tokoh fiktif mempunyai sisi kemanusiaan yang merupakan objek utama psikologi sastra. Psikologi sastra mempelajari karya sastra sebagai fenomena kejiwaan tertentu yang dialami pengarang yang tercermin dari perilaku para tokoh dalam karya sastra, terlihat saat merespon atau bereaksi terhadap diri dengan tokoh lain maupun dengan lingkunganya. Dengan demikian, gejala kejiwaaan dapat terungkap lewat perilaku tokoh dalam sebuah karya sastra. Seperti yang disampaikan oleh Purwanto (2007: 1) yang berpendapat bahwa psikologi berarti ilmu yang mempelajari tingkah laku manusia, dan yang dimaksud dengan tingkah laku ialah segala kegiatan, tindakan, perbuatan manusia baik yang kelihatan maupun yang tidak kelihatan, yang disadari maupun yang tidak disadari.

Pemahaman terhadap kejiwaan tokoh selain membantu pengarang dalam mengembangkan jalannya cerita, juga membantu pembaca dalam meresapi amanat yang disampaikan melalui karya sastra. Bermula dari pemahaman kejiwaan tokoh yang dimiliki oleh pembaca atau penikmat naskah drama akan menjadi bekal untuk menilai sekaligus memberikan apresiasinya dengan baik. Secara definitif, tujuan psikologi sastra adalah memahami aspek-aspek kejiwaan yang terkandung dalam sebuah karya sastra (Ratna, 2013: 342). Penting dalam psikologi sastra selain berperan mengkaji sastra, juga berdampak pada peningkatan pemahaman pembaca terhadap karya sastra. Pembaca akan semakin mengapresiasi naskah drama sebagai salah satu karya sastra yang bermuatan positif. Pembaca mengetahui seluk-beluk 
dari masing-masing tokoh dan kemudian memaknai amanat yang terkandung di dalam naskah drama tersebut.

Penelitian ini mengintegrasikan antara kajian psikologi sastra dengan sudut kajian konflik batin tokoh direlevansikan sebagai bahan ajar apresiasi drama pada satuan pendidikan di tingkat sekolah menengah atas. Fakta yang ditemukan dari hasil penelitian Yus Rusyana (dalam Waluyo, 2003: 1) menyampaikan bahwa minat peserta didik dalam membaca karya sastra yang paling banyak, yaitu prosa, menyusun puisi, baru kemudian drama. Hal ini disebabkan karena dalam kegiatan penghayatan terhadap naskah drama yang berbentuk dialog, masih didapati siswa yang kurang cermat dan teliti dibandingkan dengan menghayati puisi atau prosa. Terlebih lagi kurangnya rasa yang ditumbuhkan untuk percaya diri dalam menginterpretasikan atau mengkaji lebih dalam terkait karakter dan konflik yang dialami tokoh dalam naskah drama. Hal ini yang menjadi latar belakang peneliti memilih dan mengupayakan untuk memberikan solusi yang tepat dan bijak dalam pemahaman yang terbaik.

Pembelajaran apresiasi drama yang rendah tidak menutup sebab yang lain terkait dengan bahan ajar pembelajaran drama yang masih monoton. Sejalan dengan hal tersebut, Penelitian yang dilakukan oleh Erma Susilowati terhadap apresiasi drama di sekolah menengah atas, masih menemukan bahan ajar yang monoton dan menimbulkan kejenuhan belajar siswa. Penelitian ini menghadirkan naskah drama sebagai pilihan kajian dalam apresiasi drama di tingkat sekolah menengah atas. Kajian ini mengupayakan adanya solusi aplikatif terhadap kesulitan dalam pembelajaran apresiasi drama khususnya dalam hal pementasan drama.

Penelitian ini memperhatikan naskah drama "Senja Dengan Dua Kelelawar" sebagai salah satu naskah yang sangat relevan untuk diteliti dari segi psikologi sastra, karena naskah drama "Senja Dengan Dua Kelelawar" mengandung berbagai macam konflik batin yang dialami oleh para tokoh. Pemilihan naskah drama "Senja Dengan Dua Kelelawar" dengan mempertimbangkan : (1) naskah drama "Senja Dengan Dua Kelelawar" aspek psikologi tokoh yang mempunyai relevansi sebagai konsumsi masyarakat dewasa ini khususnya bagi remaja tingkat akhir, (2) naskah drama "Senja Dengan Dua Kelelawar" merupakan naskah yang ditulis dan sering 
dipentaskan pada tahun 1950 hingga tahun 1970 dan saat ini menjadi naskah marjinal hal tersebut menunjukkan pada dasarnya naskah ini berkualitas, dan (3) naskah drama "Senja Dengan Dua Kelelawar" ditulis berdasarkan kegelisahan eksistensial manusia maka mengandung pelajaran hidup yang baik untuk dimengerti oleh masyarakat secara luas.

\section{METODE PENELITIAN}

Penelitian ini dilaksanakan selama enam bulan, yaitu pada bulan Januari--Juni 2018. Pendekatan yang digunakan dalam penelitian ini adalah pendekatan penelitian kualitatif. Penelitian kualitatif mengarah pada pendeskripsian secara rinci dan mendalam mengenai tetang potret kondisi tentang apa yang sebenarnya terjadi (Sutopo, 2002:111). Data sebagai objek kajian yang penting dalam penelitian. Data dalam penelitian ini adalah data kualitatif. Pada Penelitian ini, sumber data dalam penelitian adalah subyek dari mana data dapat diperoleh (Arikunto, 2013: 129). sumber data primer dalam penelitian ini adalah naskah drama "Senja Dengan Dua Kelelawar" karya Kridjomulyo. Data penelitian ini adalah percakapan atau dialog tokoh satu dengan tokoh lain, kondisi sosial dan fisik tokoh utama, kalimat dalam bentuk ungkapan, dan tingkah laku tokoh yang menunjukkan adanya konflik batin pada tokoh. Sumber data tersebut akan menghasilkan data yang dibutuhkan dalam penelitian ini yakni data berupa konflik batin para tokoh naskah drama Senja Dengan Dua Kelelawar karya Kridjomulyo serta data berupa penjelasan terkait dengan relevansi dalam pembelajaran apresiasi drama. Teknik sampling yang digunakan adalah purposive sampling atau teknik pengambilan data yang berdasarkan pada tujuan tertentu. Teknik pengumpulan data yang digunakan dalam penelitian ini adalah dengan analisis dokumen dan wawancara. Uji validitas data yang digunakan adalah trianggulasi metode dan trianggulasi sumber data. Analisis data yang digunakan dalam penelitian ini adalah model interaktif (Miles dan Huberman, 1993: 20). 


\section{HASIL PENELITIAN DAN PEMBAHASAN}

Hasil penelitian memaparkan hasil kajian, yakni : (1) deskripsi naskah drama Senja Dengan Dua Kelelawar karya Kridjomulyo, (2) kajian perwatakan para tokoh dalam naskah Senja Dengan Dua Kelelawar karya Kridjomulyo, (3) kajian konflik batin para tokoh dalam Senja Dengan Dua Kelelawar karya Kridjomulyo, dan (4) relevansi Senja Dengan Dua Kelelawar karya Kridjomulyo sebagai bahan ajar apresiasi drama pada sekolah menengah atas. Lebih jelasnya deskripsi hasil penelitian dapat dilihat sebagai berikut.

Perwatakan para tokoh dalam naskah drama Senja Dengan Dua Kelelawar karya Kridjomulyo

Tokoh dalam karya fiksi merupakan bentuk cerminan dari tindakan manusia dalam kehidupan nyata. Setiap tokoh mempunyai perbedaan yang mendukung aktivitas pemeranan dalam karya tersebut, sehingga sangat mungkin masingmasing tokoh mempunyai sifat dan watak yang berbeda. Hal ini diperlukan untuk membangun jalannya cerita, melalui sifat dan watak yang berbeda akan memberikan peluang pada pengarang untuk memunculkan konflik dan perseteruan yang berasal dari interaksi tokoh. Pengarang memunculkan karakter tokoh melalui dua cara, yakni teknik yang digunakan oleh pengarang dalam menampilkan tokoh dalam suatu cerita yaitu teknik ekspositoris (analitik) dan teknik dramatik.

Perwatakan yang dimiliki oleh tokoh sangat berpeluang untuk dikaji. Adapun pengkajian perwatakan yang didasarkan pada dimensi tokoh, Waluyo (2011 : 21) menjelaskan bahwa watak para tokoh dalam fiksi digambarkan dalam tiga dimensi, yaitu dimensi psikis (kejiwaan) yang berkaitan dengan kondisi psikologis, sifat dan watak tokoh; dimensi fisik (jasmaniah) meliputi umur, ciri fisik, dan sebagainya; dan dimensi sosiologis (sosial masyarakat) meliputi latar belakang kekayaan, pangkat, dan jabatan.

Penelitian dikonferensikan oleh Goken Aras pada tahun 2014 dalam 3rd World Conference on Psychology and Sociology, mempresentasikan penelitiannya yang berjudul Personality and Individual Differences: Literature in Psychology, 
Psychology in Literature menemukan hubungan yang kuat antara sastra dan psikologi.

There is a very strong correlation between literature and psychology for the fact that both of them deal with human beings and their reactions, perceptions of the world, miseries, wishes, desires, fears, conflicts and reconciliations; individual and social concerns, by means of varied concepts, methods, and approaches.

Tokoh dengan berbagai macam sifat dan watak dapat dipelajari dan diambil sisi positifnya. Sebagai karya fiksi yang menjadi replikasi dari kehidupan, naskah drama Senja Dengan Dua Kelelawar mempunyai nilai humanism yang bisa diteladani melalui pemeranan dari masing-masing tokoh. Cerita dalam Senja Dengan Dua Kelelawar mampu membuka kacamata masyarakat terhadap realita lingkungan yang mempunyai dinamika kehidupan beranekaragam.

Perwatakan masing-masing tokoh dalam naskah drama Senja Dengan Dua Kelelawar karya Kridjomulyo mempunyai perbedaan, yaitu (1) Ismiyati mempunyai sifat yang keras kepala dengan keinginannya, berani berkorban demi orang yag dicintai, tidak berpikir panjang dalam mengambil keputusan; (2) Suwarto mempunyai sifat penyayang kepada istrinya, menjunjung tinggi kehormatan dan harga diri, baik hati, dan memiliki kemauan yang kuat, meski demikian Suwarto bukan tokoh yang suka dinasihati; (3) Mardikun memunyai watak yang dewasa, suka memberikan nasehat, sangat baik hati dan dermawan; (4) Mursiwi merupakan aktor yang berseberangan dengan tokoh utama, Mursiwi mempunyai watak yang curang, selalu pamer hingga membuat orang lain merasa iri dan yang palin mencolok adalah sifat materrialistis yang dimilikinya; (5) Marsudi merupakan tokoh yang turut membangun, sebagai ayah dari Ismiyati, Marsudi sangat mencintai keluarganya, menjunjung nilai dan budaya keluarga serta selalu mencurahkan perhatian pada anaknya, (6) Tomokaryo adalah tokoh pendukung yang hadir dengan watak humoris, sangat mencintai keluarga, mempunyai solidaritas dan rasa sosial yang tinggi; (7) Siswoyo merupakan tokoh yang berperan sebagai pegawai di stasiun KA, watak yang dimiliki Siswoyo hampir sama dengan Tomokaryo, Siswoyo mempunyai rasa kepedulian yang tinggi, sifat humoris dan solidaritas kepada rekan kerjanya; dan (8) Sulaiman 
adalah tokoh yang sangat sedikit adegannya namun sangat menentukan dalam penyeleseian konflik yang dibangun oleh pengarang, dalam drama Sulaiman berperan sebagai calon suami Mursiwi yang ternyata oleh Mursiwi hanya dibohongi belaka maka sifat dendam dan amarah sangat terlihat dari adegan yang diperankan dalam drama.

Beberapa tokoh dengan watak yang berbeda dalam naskah drama Senja Dengan Dua Kelelawar karya Kridjomulyo menjadi daya tarik bagi siswa untuk memahami lebih mendalam karakter yang dibangun pengarang dalam naskah tersebut. Hal tersebut akan membantu siswa dalam memainkan peran dan mengadaptasi naskah drama tanpa menghilangkan unsur keaslian, nilai kehidupan dan pesan yang ada di dalam naskah drama.

Konflik batin para tokoh dalam naskah drama Senja Dengan Dua Kelelawar karya Kridjomulyo

Konflik dalam drma berfungsi untuk menumbuhkan pengenalan nilai atau pesan dan bahkan bisa pada tahap karya sastra tersebut mampu membentuk sebuah replikasi kehidupan manusia yang pada umumnya akan menemui konflikkonflik kehidupan. Sejalan dengan pendapat Waluyo (2003: 7) dasar teks drama adalah konflik manusia yang digali kehidupannya.

Prinsip teori kepribadian Freud yang mengelompokkan kontruksi kepribadian menjadi tiga macam, yaitu $i d$, ego, dan superego. Id : bahwa Id merupakan energi psikis dan naluri yang menekan manusia agar memenuhi kebutuhan dasar seperti misalnya kebutuhan : makan, seks, menolak rasa sakit dan tidak nyaman. Id pada dasarnya berkerja dan berada di bawah alam sadar. Semua kebutuhan yang berkaitan dengan kesenangan, seperti menjauh dari ketidaknyamannan dan mencari-cari kesenangan yang bisa memuaskan. Ego : Ego (terletak di antara alam sadar dan tak sadar) yang bertugas sebagai penengah yang mendamaikan tuntunan pulsi dan larangan superego (Minderop, 2016: 21).

Ego merupakan bagian pikiran yang mampu mewakili alam bawah sadar, hal ini menjadikan Ego sebagai pendamping Id yang akan menghubungkan dengan realitas. Super Ego : Superego (terletak sebagian di bagian sadar dan sebagian lagi di bagian tak sadar) bertugas mengawasi dan menghalangi pemuasan sempurna 
pulsi-pulsi tersebut yang merupakan hasil pendidikan dan identifikasi pada orang tua, sehingga akan menghasilkan pemahaman terhadap pantas atau tidak tindakan pemuas id yang diputuskan oleh ego.

Konflik batin yang ditelaah menggunakan teori psikoanalisis Sigmund Freud sangat kuat dan solutif dalam memberikan kemudahan dalam rangka penafsiran terhadap makna yang terdapat konflik tersebut. Rezaei dan Seyyedrezaei dalam 3rd World Conference on Psychology, Counselling and Guidance (WCPCG2012) melalui jurnalnya yang berjudul The Contribution of Psychological Theories in Literary Criticism menyampaikan tentang peran psikoanalisis yang disebutnya sebagai bentuk teori kritik baru dalam sastra, mempunyai andil yang besar dalam memberikan jalan pikir yang tepat untuk menafsirkan konflik batin dalam karya sastra.

"New Criticism" provides readers with a formula for arriving at the correct interpretation of a text using-for the most part-only the text itself. This approach gives both beginning students of literature and academicians a seemingly objective approach for discovering a text's meaning. So any intelligent reader can uncover a text's hitherto-so called "hidden meaning" within a text.

Konflik batin yang beragam terjadi pada para tokoh dalam naskah drama Senja Dengan Dua Kelelawar karya Kridjomulyo, yakni 1) Marsudi dengan kesepian yang dialami, 2) Marsudi berkeinginan untuk menikahkan Ismiyatii tapi belum tercapai, 3) Ismiyati dilema harus menuruti Marsudi atau pendiriannya sendiri, 4) Ismiyati merasa cemburu dan dendam kepada Mursiwi, 5) Ismiyati menderita atas tuduhan Marsudi, sebagai dalang pembunuhan Mursiwi, 6) Marsudi mengalami kecemasan dalam pikirannya dan menyangka bahwa Ismiyati adalah pembunuh Mursiwi, 7) Ismiyati ingin hadir dalam kehidupan Suwarto, 8) Suwarto menghadapi kematian Mursiwi dengan penuh dendam, 9) Suwarto dilemma untuk menghukum pengakuan Ismiyati, dan 10) Sulaiman yang dendam karena dibohongi oleh Mursiwi.

Konflik batin yang dialami oleh tokoh dalam naskah drama Senja Dengan Dua Kelelawar karya Kridjomulyo mempunyai sisi humanism yang sangat baik untuk dimengerti dan ditumbuhkan dalam diri masyarakat. Terlihat dari Ismiyati dengan 
keteguhan hatinya dalam memperjuangkan cita dan cintanya, Suwarto dengan ketegasan pribadi dalam menghadapi kenyataan hidup yang pahit karena istrinya tercinta meninggal di umur yang muda, kesabaran mardikun dalam memberikan nasehat kepada Suwarto, dan Marsudi sebagai seorang bapak sangat menjaga dan menjunjung tinggi nilai dalam mendidik keluarganya.

Penjelasan terkait tokoh dengan karakter yang dibangun oleh pengarang mempunyai dimensi yang sangat relevan dengan dunia remaja, khususnya siswa dengan rentang umur 14--17 tahun. Pada umur tersebut, remaja sudah mengenal dengan dunia abstrak yang penuh dengan subjektifitas yang membangun, sehingga perlu adanya penguatan dalam bertindak secara benar dan terarah dengan baik. Naskah drama Senja Dengan Dua Kelelawar karya Kridjomulyo yang diberikan kepada remaja akan memberikan stimulus pada pembentukan serta pengutan id, ego dan superego dalam menetukan sikap saat pengambilan keputusan. Hal ini sangat penting dilakukan agar remaja atau siswa dengan umu 14--17 tahun mempunyai gambaran jauh ke depan dalam menjalani kehidupan bermasyarakat.

Relevansi Naskah drama Senja Dengan Dua Kelelawar Karya Kridjomulyo sebagai Bahan Ajar Apresiasi Drama pada Sekolah Menengah Atas

Pembelajaran apresiasi sastra khusunya drama membutuhkan bahan ajar yang mampu menubuhkembangkan pengetahuan, keterampilan dan sikap siswa. Tiga hal tersebut berbeda, namun mempunyai peran yang saling berkaitan dalam proses belajar. Menghadirkan sastra dalam pendidikan dan pembelajaran bukan tanpa tujuan, karena melalui pembelajaran sastra maka siswa akan mendapatkan pengalaman membaca yang berpengaruh pada kognitif, psikomotor dan afektif pada siswa. Karya sastra seperti halnya naskah drama yang digunakan sebagai bahan ajar diharapkan mampu memberikan sikap positif kepada siswa.

Bahan ajar sebagai produk yang dihasilkan oleh guru dari sebuah rencana pembelajaran yang telah disusun. Pada dasarnya, semua buku atau naskah dapat digunakan sebagai bahan belajar bagi siswa, namun perlu adanya pembedaan bahan ajar dari buku lainnya yakni dalam penyusunannya karena bahan ajar disusun berdasarkan atas kebutuhan pembelajaran yang dibutuhkan siswa, terkait 
dengan materi yang perlu dikuasai siswa dengan baik. Permendikbud nomor 8 tahun 2016 menjelaskan bahwa materi pengetahuan yang diinformasikan melalui Buku Teks Pelajaran dan Buku Non Teks Pelajaran sangat penting. Naskah drama Senja Dengan Dua Kelelawar karya Kridjomulyo termasuk dalam buku non teks pelajaran, karena naskah drama dapat digunakan sebagai bahan ajar dalam pembelajaran apresiasi drama sedang pada dasarnya naskah drama dibuat bukan bertujuan untuk pelajaran namun untuk kepentingan pementasan drama sebagai karya pementasan yang berasal dari karya sastra.

Sejalan dengan hal tersebut Koesnandar (2008) mengategorikan beberapa jenis bahan ajar berdasarkan subjeknya yang terdiri dari dua jenis antara lain: (a) bahan ajar yang sengaja dirancang untuk belajar, seperti buku, handouts, LKS dan modul; (b) bahan ajar yang tidak dirancang namun dapat dimanfaatkan untuk belajar, misalnya kliping, koran, film, iklan atau berita. Secara teoretis tersebut, naskah drama Senja Dengan Dua Kelelawar karya Kridjomulyo termasuk pada bahan yang tidak dirangcang namun dapat dimanfaatkan

Kesesuaian dalam kompetensi dasar bahasa Indonesia Kelas XI yang memuat tentang pembelajaran apresiasi drama adalah adanya kompetensi dasar dalam hal : 1) mengidentifikasi alur cerita, babak demi babak, dan konflik, 2) menganalisis isi dan kebahasaan drama yang dibaca atau ditonton, 3) mempertunjukkan salah satu tokoh dalam drama yang dibaca atau ditonton secara lisan, dan 4) mendemonstrasikan sebuah naskah drama dengan memerhatikan isi dan kebahasaan.

Relevansi naskah drama Senja Dengan Dua Kelelawar karya Kridjomulyo sebagai bahan ajar juga didasarkan pada teori yang disampaikan oleh Rahmanto (1988: 27) bahwa pemilihan bahan pengajaran sastra juga harus mempertimbangkan tiga aspek penting, yaitu sudut bahasa, segi kematangan jiwa (psikologi), dan sudut latar belakang kebudayaan siswa. Naskah drama Senja Dengan Dua Kelelawar karya Kridjomulyo dari hasil penelitian yang telah dilakukan menunjukkan kesesuai tingkat pemahaman bahasa pada siswa kelas XI, kematangan psikologi atau kejiwaan siswa dalam menerima cerita yang 
mengandung konflik batin, serta kesesuaian atau kedekatan budaya yang dalam naskah drama dengan kehidupan keseharian dari siswa.

Cerita yang disampaikan dalam naskah drama Senja Dengan Dua Kelelawar karya Kridjomulyo juga sesuai teori tugas perkembangan masa remaja menurut Havighurst sebagaimana dikutip Gunarsa (2001: 39). Teori tugas perkembangan remaja pada tingkat SMA sudah seharusnya mengenal beberapa tanggung jawab atas perkembangan yang ada di dalam diri baik berkaitan dengan diri maupun lingkungan.

Kesesuaian dalam beberapa hal, yakni (1) belajar memiliki peranan sosial dengan teman sebaya, baik teman sejenis maupun lawan jenis sesuai dengan jenis kelamin masing-masing, (2) mengembangkan kecakapan intelektual dan konsepkonsep tentang kehidupan bermasyarakat, (3) mencari jaminan bahwa suatu saat harus mampu berdiri sendiri dalam bidang ekonomi guna mencapai kebebasan ekonomi, (4) memahami dan mampu bertingkah laku yang dapat dipertanggungjawabkan sesuai dengan norma-norma dan nilai-nilai yang berlaku, dan (5) memperoleh informasi tentang pernikahan dan mempersiapkan diri untuk berkeluarga.

Hal ini diperkuat dengan beberapa pendapat informan yang ikut menanggapi naskah drama Senja Dengan Dua Kelelawar karya Kridjomulyo. Endang Maryanti, S.Pd., guru Bahasa Indonesia SMA, berpendapat bahwa naskah drama Senja Dengan Dua Kelelawar karya Kridjomulyo adalah naskah drama yang bagus karena mengandung curahan hati seorang manusia dan mengajarkan untuk jujur pada diri sendiri. Beliau juga menyampaikan bahwa naskah drama Senja Dengan Dua Kelelawar karya Kridjomulyo sangat cocok untuk digunakan sebagai bahan ajar apresiasi drama pada anak SMA kelas XI agar siswa juga memahami dan yang di masa mendatang nilai kemanusiaan yang terdapat dalam naskah bisa menjadi bekal sikap bagi siswa. Selain itu naska drama tersebut jua menggunakan bahasa cukup bagusyang mudah dipahami untuk anak seusia SMA kelas XI. Kecocokan kejiwaan dan latar belakang budaya dalam naskah drama dengan dunia anak serta pembelajaran sekarang, masih relevan seperti menghormati orang tua, pengorbanan kepada orang, membantu orang yang susah. 
Sumiyati, S.Pd., guru Bahasa Indonesia SMA, berpendapat bahwa naskah drama Senja Dengan Dua Kelelawar karya Kridjomulyo cocok untuk dijadikan sebagai bahan ajar karena bahasa yang ringan untuk siswa SMA, di dalamnya juga mengandung nilai didik yang perlu dipahami oleh siswa seperti jujur pada diri sendiri, perjuangan terhadap cita-cita. Ada juga nilai sosial yang terkandung, seperti membantu sesama, rasa empati, saling menyapa. Bahasa mudah dipahami oleh siswa bisa mengena pesan yang disampaikan. Dari jalan cerita yang sudah mengenal percintaan dan memperjuangkan mimpi yang anak SMA juga sudah mengenal. Selain itu, budaya masyarakat maupun lingkungan yang dekat dengan kehidupan siswa sehingga membuat ketertarikan tersendiri bagi naskah itu.

Selvia Putri Kumalasari, M.Pd., guru Bahasa Indonesia SMA, menyatakan pendapatnya bahwa naskah drama Senja Dengan Dua Kelelawar karya Kridjomulyo mempunyai kecenderungan untuk diminati oleh remaja. Karena dalam naskah drama tersebut mempunyai alur cerita yang sangat menarik bagi remaja, yaitu perjuangan untuk cinta. Meski cerita bisa dikatakan agak rumit, namun cukup bisa dimengerti oleh siswa SMA. Selain itu, ketertarikan dan berikut keindahan dalam naskah tersebut adalah konflik yang dimunculkan oleh pengarang sangat unik. Ditunjang dengan bahasa yang mudah dimengerti oleh siswa dan budaya yang dekat dengan siswa seperti percintaan, keluarga dan masyarakat. Secara psikologi naskah drama tersebut konflik yang digunakan juga masih dalam koridor yang masih bisa diterima oleh kejiwaan anak usia SMA sekarang.

Dian Permata Sari, S.Pd., guru Bahasa Indonesia SMA, menyatakan pendapatnya bahwa naskah drama Senja Dengan Dua Kelelawar karya Kridjomulyo bisa membangun kedekatan dengan siswa di SMA seperti perihal soal perasaan apalagi ada unsur pengorbanan dalam percintaan itu masih relevan, bagi remaja sekarang pun itu sudah bukan hal yang baru dikenal. Selain itu, secara bahasa drama dengan sastra yang cukup bagus dari setiap peristiwa. Nilai kehidupan yang perlu dimengerti oleh siswa juga disampaikan dalam naskah tersebut, seperti toleransi antar tokoh, memaafkan kesalahan orang lain, 
memperhatikan lingkungan sosial yang secara tidak langsung menjadi nilai positif tersendiri dari naskah drama Senja Dengan Dua Kelelawar karya Kridjomulyo.

Secara bahasa, naskah drama tersebut sudah layak untuk dikonsumsi oleh siswa SMA. Karena tidak menggunakan bahasa yang berlebihan sehingga siswa mudah dalam memahami pesan dan amanat yang disampaikan pengarang lewat karya tersebut. Selain itu, secara perkembangan psikologi siswa juga masih relevan untuk disajikan dalam pembelajaran apresiasi drama. Karena naskah drama tersebut mengangkat permasalahan yang relatif masih bisa diterima oleh siswa, yakni masalah keluarga, percintaan, dan masyarakat yang mestinya harus dimengerti oleh siswa. Begitu pula, dari segi latar budaya dalam drama tersebut yang masih dekat dengan kehidupan remaja sekarang.

Penjelasan dan pemaparan hasil kajian psikologi sastra naskah drama Senja Dengan Dua Kelelawar karya Kridjomulyo menunjukan bahwa naskah drama Senja Dengan Dua Kelelawar karya Kridjomulyo relevan untuk dijadikan sebagai bahan ajar apresiasi drama di tingkah sekolah menengah atas.

\section{SIMPULAN}

Berdasarkan analisis data yang dilakukan terhadap Naskah Drama Senja Dengan Dua Kelelawar Karya Kridjomulyo dapat disimpulkan bahwa watak para tokoh yang ada dalam naskah drama dapat dijelaskan berdasarkan beberapa cara melukiskan watak yaitu jalan pikiran tokoh, reaksi tokoh terhadap suatu peristiwa yang terjadi, dan anggapan tokoh tersebut terhadap tokoh lain.

Perwatakan para tokoh dalam Naskah Drama Senja Dengan Dua Kelelawar Karya Kridjomulyo memiliki perbedaan dan persamaan. Perbedaan dapat terlihat dari Tokoh Mursiwi dan Ismiyati, mereka berdua adalah perempuan, namun Ismiyati merupakan sosok yang setia sedang Mursiwi bukanlah wanita yang setia, dia hanya melihat harta bahkan tega meninggalkan suaminya hanya untuk menikah lagi dengan orang yang lebih berharta. Sedang persamaan dari para tokoh terlihat dari keinginan untuk merasakan kedamaian dan keharmonisan baik dalam rumah tangga maupun dalam bermasyarakat, seperti halnya Bapak Kepala stasiun yang memberikan nasehat kepada Suwarto agar memperhatikan keluarga, 
pekerjaan dan sikapnya. Tomokarto yang sangat menyanyangi keluarga dan sangat peduli dengan rekan kerjanya.

Hasil analisis perwatakan para tokoh digunakan untuk mengungkap konflik batin yang dialami para tokoh yang didasarkan pada peran id, ego, dan, superego dalam diri setiap tokoh. Pada Naskah Drama Senja Dengan Dua Kelelawar Karya Kridjomulyo terdapat beberapa keragaman tokoh dalam mengendalikan id, melihat dan menyelaraskan ego, serta mengedepankan superego sehingga mampu memberikan keputusan bertindak dengan tepat untuk keluar dari konflik batin yang sedang dihadapinya.

Naskah Drama Senja Dengan Dua Kelelawar Karya Kridjomulyo relevan dijadikan sebagai bahan ajar apresiasi drama pada Sekolah Menengah Atas. Relevansi naskah drama Senja Dengan Dua Kelelawar karya Kridjomulyo sebagai bahan ajar dilihat dari tiga aspek penilaian, yakni mempertimbangkan sudut bahasa, sudut kematangan jiwa (psikologi), dan sudut latar belakang budaya siswa. Secara bahasa menggunakan bahasa tulis yang sesuai dengan jenjang sekolah menengah atas, dalam naskah terdapat diksi-diksi baru yang menambah wawasan kebahasaan siswa. Bahasa yang digunakan juga mudah dimengerti oleh siswa. Secara psikologi peristiwa yang yang dialami tokoh dalam naskah juga terjadi di dunia nyata. Selain itu, siswa pada jenjang sekolah menengah atas (umur 14-17 tahun) sudah mempunyai imajinasi serta mengerti secara pemahaman kejiwaan dalam hal romantisme, keluarga dan bermasyarakat, sehingga naskah drama Senja Dengan Dua Kelelawar karya Kridjomulyo sesuai dengan sudut kematangan jiwa (psikologi) siswa kelas XI. Secara sudut latar belakang budaya siswa terlihat dengan jelas oleh percakapan para tokoh yang menggunakan budaya yang sangat dekat dengan kehidupan siswa di masa SMA yang sudah mengenal keluarga, asmara dan masyarakat.

Selain itu, analisis mengenai perwatakan tokoh dan konflik batin tokoh relevan dijadikan bahan ajar karena dapat menjadi contoh analisis tokoh dan penokohan naskah drama. Watak tokoh yang mampu mengendalikan diri dalam menghadapi konflik batin dapat menimbulkan efek ikutan yang dapat dicontoh oleh siswa. Hal itu dapat membantu siswa dalam upaya memperbaiki kualitas karakter dalam 
dirinya dan sesuai dengan kurikulum 2013 yang menekankan adanya pendidikan yang bermuatan karakter.

\section{DAFTAR PUSTAKA}

Aras, Goken. (2015). Personality and Individual Differences: Literature in Psychology, Psychology in Literature. Procedia - Social and Behavioral Sciences, 185 : 250 - 257. Diperoleh pada 25 Mei 2018, dari https://ac.elscdn.COM/S1877042815022454/1-s2.o-S1877042815022454-main.pdf?_tid=35c6ade76db3-416o-bCB3-dfd42cea2coo\&acdnat $=1527223199$ abbo3deaea8c99agf7752b2bb89CE781

Budiantoro, W dan Mardianto, W. (2016). Aplikasi Teori Psikologi Sastra. Purwokerto: Penerbit Kaldera

Budianta, M dkk. (2002). Membaca Sastra: Pengantar Memahami Sastra untuk Perguruan Tinggi. Depok: Indonesiatera.

Dewojati, C. (2010). Drama: Sejarah, Teori, dan Penerapannya. Yogyakarta: Gadjah Mada University Press

Effendi, A. ( 2002). Diktat Kuliah Tealaah Drama. Yogyakarta: Fakultas Bahasa dan Seni Universitas Negeri Yogyakarta.

Endraswara, S. (2013). Metodologi, Penelitan Sastra Epistemologi, Model, Teori, dan Aplikasi. Yogyakarta: Caps

Gunarsa, S.D., dan Gunarsa, Y.S. (2001). Psikologi Praktis: Anak, Remaja dan Keluarga. Jakarta: BPK Gunung Mulia

Kasnadi dan Sutejo. (2010) Kajian Prosa: Kiat Menyisir Dunia Prosa. Yogyakarta: Pustaka Felicha dan Spectrum

Koesnandar. (2008). Pengembangan Bahan Ajar Berbasis Web. [Online] tersedia di http://www.teknologipendidikan.net

Lestari, I. (2013). Pengembangan Bahan Ajar Berbasis Kompetensi. Padang: Akademia Permata.

Miles dan Huberman. (1993). Analisis Data Kualitatif, Buku Sumber tentang Metode-metosde Baru. Jakarta: UI Press.

Minderop, A. (2016). Psikologi Sastra; Karya Sastra, Metode, Teori, dan Contoh Kasus. Jakarta: Yayasan Pustaka Obor Indonesia 
Moleong, L.J. (2011). Metodologi Penelitian Kualitatif. Bandung:Remaja Rosdakarya.

Nurgiyantoro, B. (2013). Teori Pengajaran Fiksi. Yogyakarta: Gadjah Mada University Press

Nasution. (1992). Metode Penelitian Naturalistik Kualitatif. Bandung: Penerbit Tarsito.

Rahmanto, B. (1988). Metode Pengajaran Sastra. Yogyakarta: Kanisius

Ratna, N. K. (2013). Teori, Metode, dan Teknik Penelitian Sastra. Yogyakarta: Pustaka Pelajar.

Rezaei, A. \& Seyyedrezaei, S. H. (2013). The Contribution of Psychological Theories in Literary Criticism. Procedia - Social and Behavioral Sciences, 84 : 1908 - 1911. Diperoleh pada 25 Mei 2018, dari https://ac.elscdn.COM/S1877042813019289/1-s2.o-S1877042813019289-main.pdf?_tid=45a95873oo2b-40ae-84035f67ac5179a6\&acdnat=1527229751_6062C32FBFA93801804b20505b5CE37b

Rokhmansyah, A. (2014). Studi dan Pengkajian Sastra; Perkenalan Awal terhadap Ilmu Sastra. Yogyakarta: Graha Ilmu

Suaka, I. N. (2014). Analisis Sastra Teori dan Aplikasi. Yogyakarta: Penerbit Ombak

Sugiyono. (2010). Metode Penelitian Kuantitatif dan Kualitatif dan $R \& D$. Bandung: Alfabeta

Sutopo, H.B. (2002). Metodologi Penelitian Kualitatif Dasar Teori dan Terapannya dalam Penelitian. Surakarta: Sebelas Maret University Press

Waluyo., H. J. (2011). Pengkajian dan Apresiasi Prosa Fiksi. Surakarta : UNS Press . (2003). Drama (Teori dan Pengajarannya). Yogyakarta: Penerbit Hanindita

. (2007). Drama Naskah, Pementasan, dan Pengajarannya. Surakarta: UNS Press.

Wirajaya, A. Y., \& Sudarmawarti. (2008). Berbahasa dan Bersastra Indonesia untuk SMP/MTs Kelas VIII. Surakarta: CV Putra Nugraha. 